\title{
Annual dynamics of benthic foraminiferal populations in the Tramandaí-Armazém Lagoon, southern Brazil
}

\author{
Eduarda Pacheco Martins ${ }^{1, *} \odot$, Karlos Guilherme Diemer Kochhann๑, Cristianini Trescastro Bergue ${ }^{2} \odot$
}

\begin{abstract}
1 Universidade do Vale do Rio dos Sinos (UNISINOS), Technological Institute of Micropaleontology (itt Fossil) - (C11 Avenida Unisinos, 950 - Cristo Rei - 93022-750 - São Leopoldo - RS - Brazil).

2 Universidade Federal do Rio Grande do Sul (UFRGS), Centro de Estudos Costeiros Limnológicos e Marinhos (CECLIMAR) - (Av. Tramandaí, 976 - Imbé - 95625-000 - RS - Brazil).

*Corresponding author: eduardapachecomartins@gmail.com
\end{abstract}

\section{Abstract}

Modern coastal environments are considered highly selective and dynamic, not only due to the natural variability of physical and chemical parameters, but also because of anthropogenic contamination. Our study aims to identify environmental and/or anthropogenic factors influencing benthic foraminiferal abundances over a period of one year in the Tramandaí-Armazém Lagoon, southern Brazil. Assemblages were composed exclusively of agglutinated species assigned to the genera Trochammina, Trochamminita, Ammotium, Haplophragmoides and Miliammina. Total abundances varied throughout the year, reaching the highest values during the wetter months of March and July, when living and dead assemblages became dominated by Ammotium salsum. This pattern is likely related to salinity fluctuations due to changes in freshwater input that, consequently, affected the amount of organic matter (e.g., phytodetritus) brought into the lagoon by surrounding drainages. To assess the impact of anthropogenic pollution, we evaluated total relative abundances of deformed tests in the Tramandaí-Armazém Lagoon. Relative abundances of deformed tests were the highest during the months of January and March, when contaminant (e.g., sewage) discharge was probably increased due to the seasonal population growth in the region.

Descriptors: estuarine environments, anthropogenic contamination, coastal plain, bioindicators.

\section{INTRODUCTION}

Benthic foraminifera are distributed globally in the marine realm, from estuarine areas to abyssal plains, reflecting the remarkable abundance and diversity of this group of organisms. Since benthic foraminifera are sensitive to natural (e.g., salinity, temperature, $\mathrm{pH}$, food availability) and anthropogenic (trace elements concentration) changes, they are extensively applied as bioindicators of environmental quality (Schönfeld et al., 2012). This application of benthic foraminifera was developed in the 1960's and increased in popularity

Submitted on: 20-April-2020

Approved on: 05-January-2021

Associate Editor: Fabrizio Frontalini

2021 The authors. This is an open access article distributed under the terms of the Creative Commons license. since then, because evaluating human impacts on coastal areas became a major modern concern (e.g., Geslin et al., 2002; Bouchet et al., 2018; Martins et al., 2018; Raposo et al., 2018; Frontalini et al., 2018). Benthic foraminifera from coastal areas respond to environmental changes by changing density and diversity, structure of assemblages and/or morphology of tests (Murray, 1991). Tests can display deformities as a response to trace element contamination and the disposal of domestic residues and other contaminants, such as liquid hydrocarbons, into coastal environments (Coccioni et al., 2009; Frontalini et al., 2009).

Transitional environments of coastal plains, such as lagoons and estuaries, are considered highly selective due to high frequency changes in the balance between marine incursions and freshwater input. In Brazil, these environments are impacted by 
high population densities, inasmuch as $26.6 \%$ of the Brazilian population lives in coastal areas (IBGE, 2010). The cities of Imbé and Tramandaí, for instance, which surround our study area (the Tramandaí-Armazém Lagoon), do not have comprehensive sewage treatment plants. According to the Sistema Nacional de Informações sobre Saneamento (SNIS, 2017), the municipality of Tramandaí treats $28 \%$ of domestic residues, while in the municipality of Imbé only $0.5 \%$ of domestic residues are treated. This issue is aggravated during summer months, when population increases conspicuously from 47,558 to 95,740 inhabitants in Tramandaí, and from 20,618 to 61,045 inhabitants in Imbé (Zuanazzi and Bartels, 2016).

There are comprehensive studies on benthic foraminifera mixohaline environments from the Rio Grande do Sul coastal plain (e.g., Closs, 1962; Closs and Madeira, 1962, 1967, 1971; Closs and Medeiros, 1967; Leipnitz et al., 2003). However, these studies were mainly focused on the geographic distribution of taxa and on physical and chemical characterizations of the lagoons and associated lakes (e.g., Würdig, 1987; Leipnitz et al., 2014). Here we present the first characterization of the intra-annual variability of the benthic foraminiferal populations of the Tramandaí-Armazém Lagoon. We compare changes in the composition of benthic foraminiferal assemblages with meteorological parameters over a period of one year, to assess possible natural and/or anthropogenic influencing factors.

\section{METHODS}

\section{STUDY AREA}

The study area comprises proximal surface deposits of the Pelotas Basin (coastal plain of the Rio Grande do Sul state), whose architecture was shaped by an extensive system of alluvial fans and recurrent transgressive-regressive events related to Quaternary glacio-eustatic cycles. This setting generated a series of lagoon-barrier systems (Tomazelli and Villwock, 2005; Barboza et al., 2008). The barriers formed during transgressive maxima and isolated interconnected lagoons and lakes, aligned dominantly in a northsouth direction, from the South Atlantic Ocean. Today, only three of these water bodies are directly connected to the ocean, the Tramandaí-Armazém (studied herein), Patos and Mirim lagoons.

\section{Tramandaí-Armazém Lagoon}

The Tramandaí-Armazém Lagoon covers $18.8 \mathrm{~km}^{2}$ on the northern coast of Rio Grande do Sul, between the latitudes of $29^{\circ} 56^{\prime} 45^{\prime \prime}$ and $30^{\circ} 00^{\prime} 12^{\prime \prime}$ South and the longitudes of $50^{\circ} 07^{\prime} 14^{\prime \prime}$ and $50^{\circ} 10^{\prime} 55^{\prime \prime}$ West (Figure 1).The lagoon defines the border between the municipalities of Tramandaí and Imbé. It is part of the Tramandaí lagoonal system, which is defined by a cluster of lakes, extending from the Itapeva Lake (to the north) to the Cerquinha Lake (to the south), interconnected by natural channels and connected to the ocean by the Tramandaí-Armazém Lagoon (Würdig,1987).

The lagoon has mixohaline to fresh waters, with salinities corresponding to oligohaline waters (i.e., 0.5 to 5.0\%o) (Leipnitz et al., 2014). It is mainly influenced by seasonal changes in fluvial discharge and meteorological tides, related to the subtropical climate setting, and less strongly by astronomical micro-tides, with an amplitude of about $30 \mathrm{~cm}$. Regional climate is classified as humid subtropical (Cfa) without a dry season (Hasenack and Ferraro, 1989). Mean annual temperature is $20^{\circ} \mathrm{C}$, with average thermal amplitude of $9.5^{\circ} \mathrm{C}$. Precipitation is uniform throughout the year, with a small increase during wintertime, due to the migration of polar cyclones, and averages an accumulated precipitation of about 1,300 $\mathrm{mm}$ per year.

According to Tabajara and Dillemburg (1997), the Tramandaí-Armazém Lagoon has an average depth of $1.0 \mathrm{~m}$, reaching a maximum depth of $1.4 \mathrm{~m}$ in the Tramandaí (northward) sector. Sedimentation in the region is characterized by coastal Cenozoic deposits, dominated by sandy sediments deposited by marine and aeolian processes. Fine grained sediments in the lagoon are mainly delivered by the Tramandaí River and generated by the weathering of volcanic rocks of the Serra Geral Group. Accumulation of fine-grained sediments is concentrated in the central region of the lagoon, while coarser sediments concentrate closer to the margins. This pattern of sediment distribution is associated to the action of waves, lagoonal currents and dominant NE winds (Tabajara and Dillemburg, 1997).

\section{Data ACQUisition}

We collected surface sediments from the Tramandaí-Armazém Lagoon, at two fixed stations (Figure 1), over a period of one year. Sampling 


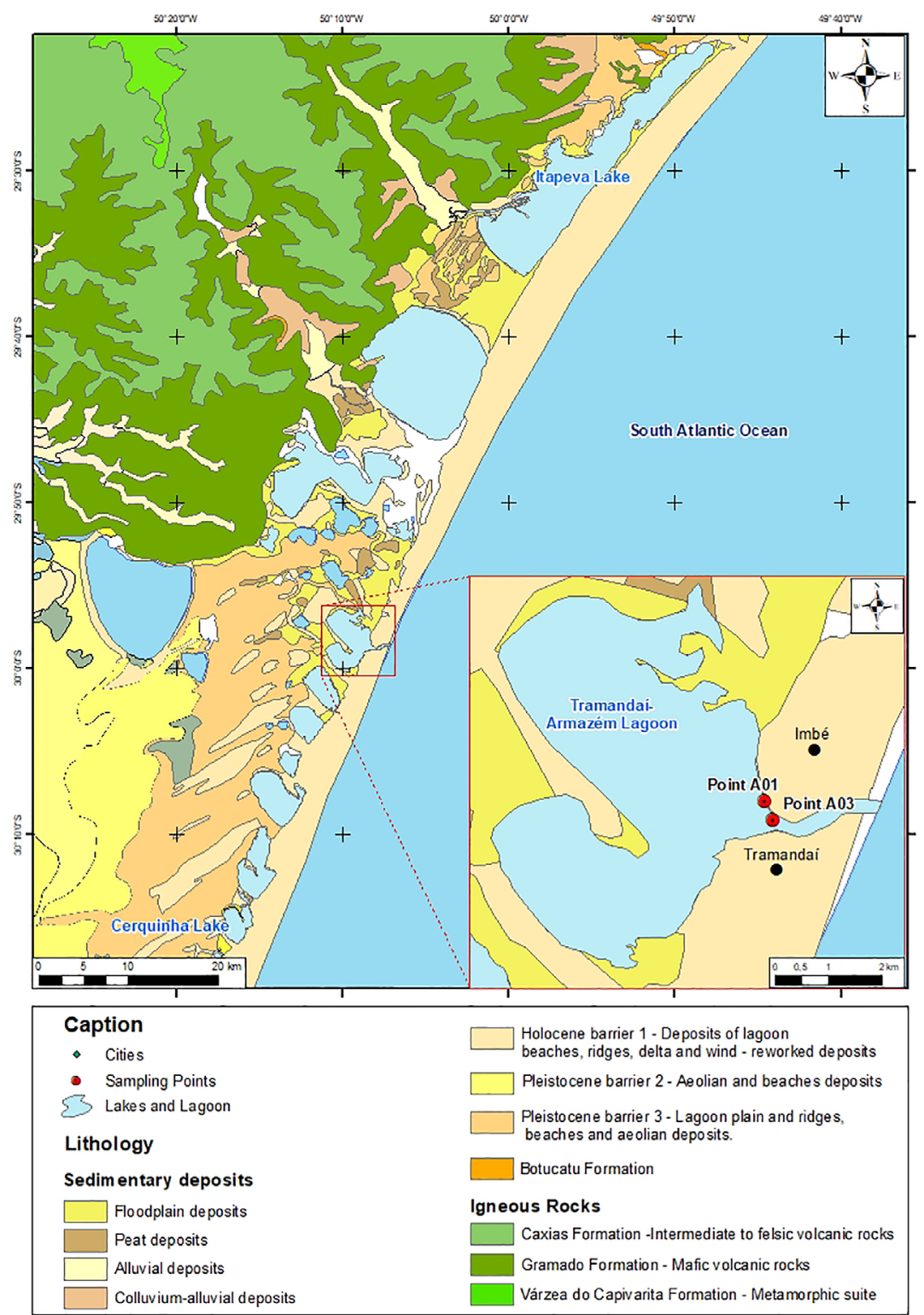

Figure 1. Geologic map of the northern coastal plain of Rio Grande do Sul, Brazil, with the detailed location of the Tramandaí-Armazém Lagoon. Lithologic units are from Wildner et al. (2008). Sampling stations (points) are marked as red circles in.

occurred in October 2018, January, March, July and September 2019. The two stations are located at the northeastern margin of the lagoon (Figure 1); one close to the Centro de Estudos Costeiros, Limnológicos

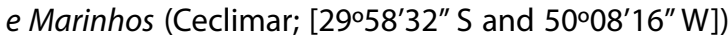
and another station closer to the connection to the

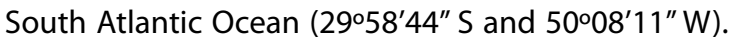
In the data analysis, both stations were considered together because there were no significant changes in benthic foraminiferal assemblages. We collected sediments with a $50 \mathrm{~mL}$ syringe, dividing the sediments into base (lower $25 \mathrm{~mL}$ ) and top (upper
$25 \mathrm{~mL}$ ). The two subsamples were preserved in a solution of $70 \%$ alcohol and stained with Rose Bengal to differentiate between living and dead foraminifera. We focused our study on the samples representing the upper $25 \mathrm{~mL}$ of sediments, which to a sediment thickness of $2.5 \mathrm{~cm}$. Salinity and $\mathrm{pH}$ were measured in situ with a Hanna refractometer and $\mathrm{pH}$ color strips. The study sample collection was registered at the Sistema Nacional de Gestão do Patrimônio Genético e do Conhecimento Tradicional Associado (SisGen) and the Sistema de Autorização e Informação em Biodiversidade (Sisbio). 
Selection of benthic foraminifera was conducted in the Rose Bengal and alcohol solution and all specimens in the volume of $25 \mathrm{ml}$ were collected. Species identifications were based on previous studies in the area as well as on original species descriptions (Ellis and Messina Catalog). Characteristic specimens were imaged in a Zeiss EVO MA 15 scanning electron microscope (SEM) and under a Zeiss DiscoveryV20 stereomicroscope at the Technological Institute of Micropaleontology (itt Fossil -UNISINOS University). On the spot elemental analyses of benthic foraminiferal tests (with at least one specimen analyzed for each identified species) were performed using an energy dispersive spectroscopy (EDS) system coupled to the SEM.

For comparison, we also compiled monthly mean air temperatures $\left({ }^{\circ} \mathrm{C}\right)$ and monthly accumulated precipitation $(\mathrm{mm})$ in the region between $17^{\text {th }}$ October 2018 and $30^{\text {th }}$ September 2019. These data were collected by the automated meteorological station of Tramandaí and were made available by the Instituto Nacional de Meteorologia (INMET; http://www.inmet.gov.br).

\section{RESULTS}

\section{Benthic foraminiferal abUNDANCE CHANGES IN THE Tramandaí-Armazém Lagoon}

The benthic foraminiferal community monitored between October 2018 and September 2019 presented large variations in total abundances (Table 1). Living and dead specimens summed up to 36 recovered specimens in October 2018 and 42 recovered specimens in January 2019. Total counts peaked in March and July 2019 when 154 and 102 specimens (living and dead specimens considered together) were recovered, respectively. In September 2019, 38 living and dead specimens were recovered.
Assemblages are composed of Ammotium salsum, Haplophragmoides wilberti, Miliammina earlandi, Trochammina inflata and Trochamminita salsa (Figure 2; Table 1). These species present agglutinated tests and are characteristic of muddy and brackish coastal marine environments (Murray, 2006; Moreno et al., 2017). Variations in the abundances of living and dead individuals assigned to these species, over the time span of one year, are shown in Figure 3.

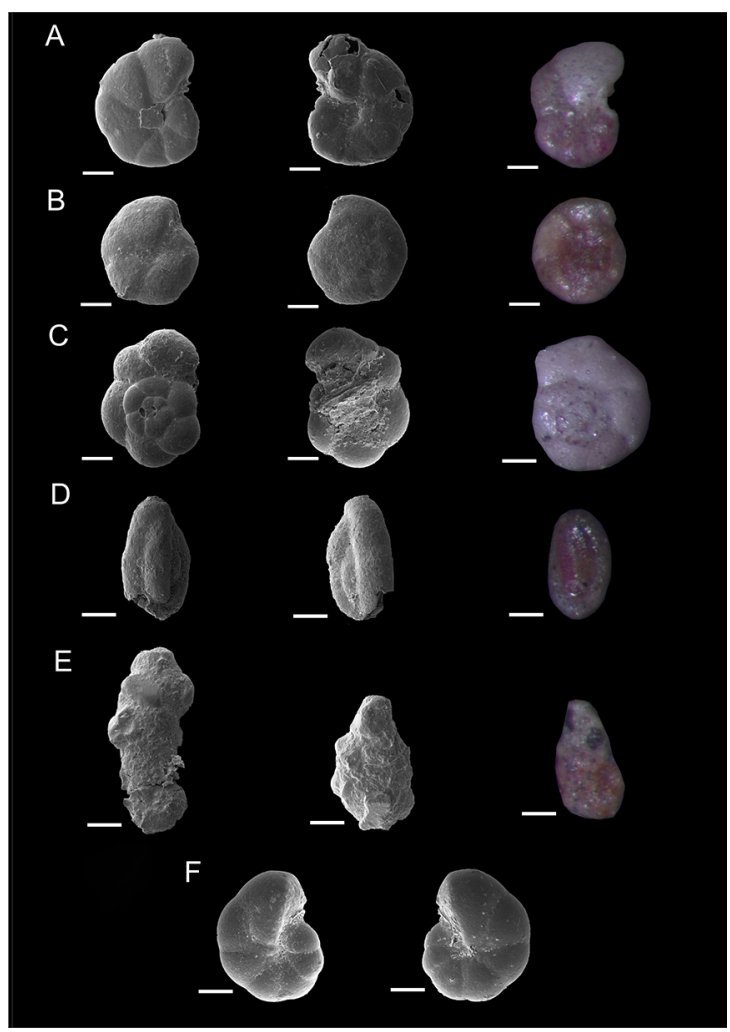

Figure 2. Scanning electron and optical micrographs of benthic foraminifera recovered from the Tramandaí-Armazém Lagoon. Optical micrographs show living specimens stained with Rose Bengal. A: Trochamminita salsa (Cushman and Brönnimann, 1948): B-C: Trochammina inflata (Montagu, 1808); D: Miliammina earlandi (Loeblich and Tappan, 1955); E: Ammotium salsum (Cushman and Brönnimann, 1948); F: Haplophragmoides wilberti (Andersen, 1953). Scale bars represent $100 \mu \mathrm{m}$.

Table 1. Total number of specimens (living and dead) recovered for each sampling survey in the Tramandaí-Armazém Lagoon. Numbers in brackets refer to living specimens. Counts refer to the two sampling stations combined.

\begin{tabular}{|c|c|c|c|c|c|c|c|c|c|}
\hline \multirow{2}{*}{$\begin{array}{l}\text { Date } \\
\text { Point }\end{array}$} & \multicolumn{2}{|c|}{ October 2018} & \multicolumn{2}{|c|}{ January 2019} & \multicolumn{2}{|c|}{ March 2019} & \multicolumn{2}{|c|}{ July 2019} & \multirow{2}{*}{$\begin{array}{c}\text { September } 2019 \\
\text { dead }\end{array}$} \\
\hline & living & dead & living & dead & living & dead & living & dead & \\
\hline Haplophragmoides wilberti & 0 & 12 & 2 & 13 & 0 & 24 & 0 & 10 & 15 \\
\hline Trochammina inflata & 2 & 6 & 1 & 8 & 2 & 16 & 1 & 8 & 2 \\
\hline Ammotium salsum & 0 & 0 & 0 & 1 & 21 & 41 & 17 & 41 & 18 \\
\hline Miliammina earlandi & 1 & 12 & 0 & 1 & 3 & 14 & 3 & 5 & 1 \\
\hline Trochamminita salsa & 3 & 0 & 1 & 15 & 3 & 30 & 0 & 17 & 2 \\
\hline Total specimens per month & $\begin{array}{l}36 \\
(6)\end{array}$ & & $\begin{array}{l}42 \\
(4)\end{array}$ & & $\begin{array}{l}154 \\
(29)\end{array}$ & & $\begin{array}{l}102 \\
(21)\end{array}$ & & 38 \\
\hline
\end{tabular}



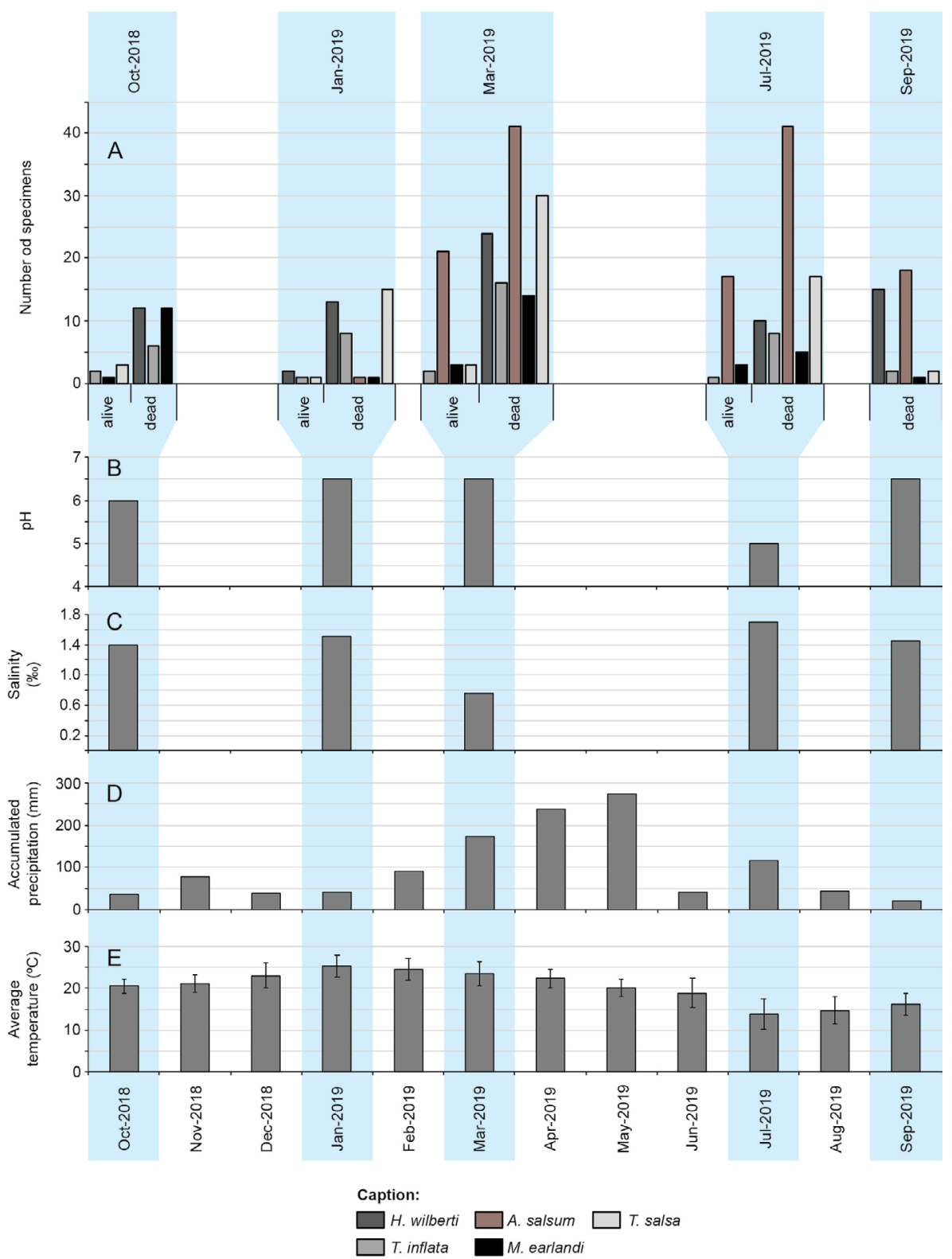

Figure 3. Changes in benthic foraminiferal assemblages over approximately one year in the Tramandaí-Armazém Lagoon. Total counts of living and dead specimens for each species $(\mathrm{A})$, are compared with in situ water $\mathrm{pH}(\mathrm{B})$ and salinity $(\mathrm{C})$ measurements, monthly accumulated precipitation (D) and monthly mean air temperatures (E) between $17^{\text {th }}$ October 2018 and 30 $0^{\text {th }}$ September 2019. Meteorological data are from INMET (http:// www.inmet.gov.br); error bars in E represent the standard deviation of measured values. Blue shading represents sampling months (campaigns).

Despite the low numbers of recovered specimens, one important feature of our dataset is that the main abundance trends are depicted by the counts of either living, dead, as well as the sum of living and dead specimens (Table 1; Figure 3). For instance, the increases in total benthic foraminiferal counts in the months of March and July 2019 were mainly driven by A. salsum occurrences in both living $(n=21$ specimens in March and $n=17$ specimens in July) and dead ( $n=$ 41 specimens in March and $n=41$ specimens in July) assemblages (Table 1; Figure 3). Relative abundances of deformed tests (Figure 4) among living and dead specimens ranged between 5.3\% (September 2019) and $16.7 \%$ (January 2019), averaging 12.6\% (Table 2).

\section{Physical and chemical parameters of the water} AND SEASONAL WEATHER PATTERNS

During sampling, water $\mathrm{pH}$ showed values of 5.0 (July 2019), 6.0 (October 2018) and 6.5 (January, March and September 2019) (Table 3; Figure 3). Water 


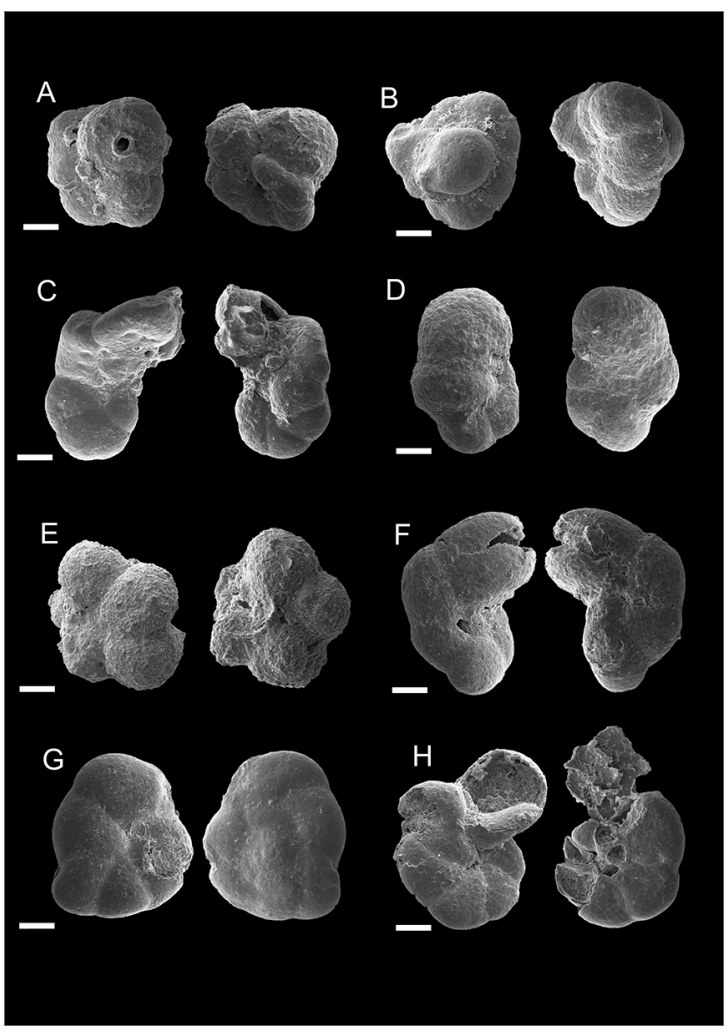

Figure 4. Examples of test deformities observed among benthic foraminifera recovered from the Tramandaí-Armazém Lagoon. Assemblages present Trochamminita salsa specimens with modifications in the position of the aperture $(A)$ and abnormal growth of chambers (C, D, F, G and H), as well as Trochammina inflata specimens with abnormal growth of chambers (B and $E)$. Scale bars represent $100 \mu \mathrm{m}$. salinity varied between $0.8 \%$ (March 2019) and 1.7\%o (July 2019), with an average of 1.5\% (Table 3; Figure 3). Therefore, we can suggest that lagoonal waters at the sampling points were oligohaline (0.5-3.0\%o) and slightly acidic.

Mean surface (air) temperature in the region was about $20{ }^{\circ} \mathrm{C}$, ranging from $14.8^{\circ} \mathrm{C}$ (July 2019) to $24.9^{\circ} \mathrm{C}$ (January 2019) (Figure 3). Monthly accumulated precipitation averaged $78.5 \mathrm{~mm}$ (Figure 3), ranging between $22.0 \mathrm{~mm}$ (September 2019) and 174.6 mm (March 2019).

\section{Elemental Analyses}

EDS elemental analyses on the tests of the recovered agglutinated benthic foraminifera reflect mainly the composition and source of sediments delivered to the Tramandaí-Armazém Lagoon. Tests present high counts for $\mathrm{Si}, \mathrm{K}, \mathrm{Al}, \mathrm{Fe}, \mathrm{Mg}$ and $\mathrm{Ti}$ (Figure 5). It probably reflects the presence of silicates in the sand fraction of the Cenozoic coastal deposits. $\mathrm{K}$ and Al are probably contained in residual clays that are the result of the chemical weathering of crystalline rocks (Croudace and Rothwell., 2015). Sediments generated by the weathering of volcanic rocks assigned to the Serra Geral Group are delivered to the lagoon by the discharge of the Tramandaí River, and their contribution as agglutinated particles is probably reflected by the presence of $\mathrm{Mg}$, Fe and Ti. Heavier minerals, such as zircons, were identified on the tests of Ammotium salsum (Figure 5).

Table 2. Counts of deformed tests per species for each sampling survey in the Tramandaí-Armazém Lagoon. Counts refer to the two sampling stations combined.

\begin{tabular}{|c|c|c|c|c|c|}
\hline Date & October 2018 & January 2019 & March 2019 & July 2019 & September 2019 \\
\hline Total foraminiferal counts & 36 & 42 & 154 & 102 & 38 \\
\hline Haplophragmoides wilberti & 3 & 3 & 5 & 2 & 1 \\
\hline Trochammina inflata & 1 & 0 & 2 & 0 & 0 \\
\hline Trochamminita salsa & 1 & 4 & 18 & 9 & 1 \\
\hline Total deformed tests & 5 & 7 & 25 & 11 & 2 \\
\hline$\%$ deformed tests & 13.9 & 16.7 & 16.2 & 10.8 & 5.3 \\
\hline
\end{tabular}

Table 3. In situ water salinity and pH measurements performed in the Tramandaí-Armazém Lagoon during sampling. Mean values for the two sampling stations are shown.

\begin{tabular}{lccccc}
\hline & October 2018 & January 2019 & March 2019 & July 2019 & September 2019 \\
\hline Salinity (\%) & 1.40 & 1.51 & 0.76 & 1.70 & 1.46 \\
$\mathrm{pH}$ & 6.0 & 6.5 & 6.5 & 5.0 & 6.5 \\
\hline
\end{tabular}



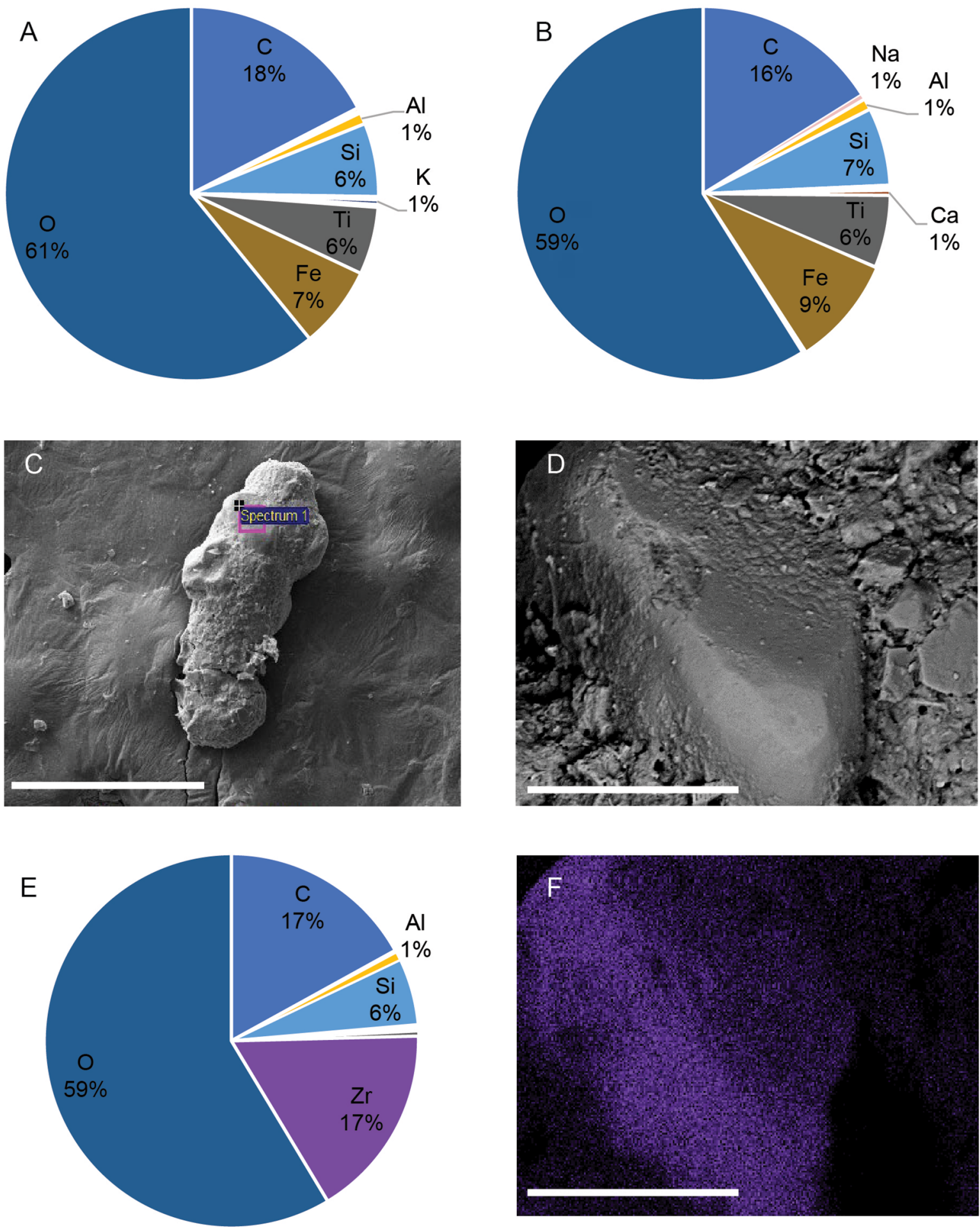

Figure 5. Elemental composition of benthic foraminiferal agglutinated tests, which reflect the composition of the most abundant sediments found in the Tramandaí-Armazém Lagoon. A-B: Mean elemental composition of two A. salsum tests based on four EDS spectra each (only elemental concentrations $>1 \%$ are shown). C-F: An example of heavy mineral (zircon) agglutinated to an A. salsum test. E: Elemental composition of the EDS spectrum on the zircon grain located in $5 C$ (only elemental concentrations $>1 \%$ are shown). F: Zirconium (Zr) distribution map (purple pixels) of the zircon crystal shown in 5 . Scale bars represent $300 \mu \mathrm{m}$ in $5 \mathrm{C}$ and $50 \mu \mathrm{m}$ in 5D-E. 


\section{DISCUSSION}

General CHARACTERISTICS AND SEASONAL VARIABILITY OF BENTHIC FORAMINIFERAL ASSEMBLAGES

Salinity changes tend to control the distribution of benthic foraminifera in the Tramandaí-Armazém Lagoon (Closs and Madeira, 1967; Leipnitz et al., 2014). All recovered species are typical of coastal environments (e.g., Leipnitz et al., 2014), present agglutinated tests and occur in low diversity and abundance assemblages, presumably due to the highly dynamic nature of the lagoonal environment. The dominance of agglutinated forms is in accordance with previous observations for the lagoon, as coastal environments are known for being rich in agglutinated foraminifera (Murray, 2006). Species such as Ammotium salsum, Trochamminita salsa and Miliammina earlandi have been previously reported for the Tramandaí-Armazém Lagoon region, whereas calcareous forms co-occur with agglutinated species mainly in the channel connecting the lagoon to the ocean (Closs and Madeira, 1967; Leipnitz et al., 2014).

Seasonal benthic foraminiferal abundance changes in the Tramandaí-Armazém Lagoon correlate to variations in water and meteorological parameters. This is mostly the case for the living assemblages, since dead assemblages can reflect the composition and abundance of more than one foraminiferal generation. Populations increased during March and July 2019, correlated to increased accumulated precipitation and, consequently, lower salinities (during March) in the lagoon (Figure 3). Mean air temperature and water $\mathrm{pH}$ remained relatively constant during the studied period, except during July 2019, when both values decreased. Salinities increased, despite increased accumulated precipitations in July 2019 (Figure 3). During our field work in July 2019, we also observed higher concentration of suspended particles in the water that could be related to increased input and deposition of organic matter, which, like $\mathrm{pH}$, can also influence foraminiferal assemblages (e.g., Bouchet et al., 2018).

Our observation that in March and July 2019 living, and to a lesser extend dead, benthic foraminiferal assemblages were dominated by Ammotium salsum supports the hypothesis that increased monthly accumulated precipitation drove drops in water salinity. Ammotium salsum is known to tolerate a wide salinity range (Murray, 1991). Moreover, it is an infaunal taxon (Murray, 2006) that likely thrived under increased food/organic matter supply (e.g., phytodetritus), brought to the Tramandaí-Armazém Lagoon by enhanced surface runoff during the wetter months of March to July 2019. Trochammina salsa, which can thrive under enhanced precipitation and freshwater input into coastal environments (Moreno et al., 2017), also significantly increased in abundance among dead specimens in March and July 2019 (Figure 3).

Leipnitz et al. (2014) suggested that the recent population growth in the area surrounding the lagoon could increase the deposition of organic matter, eventually lowering water $\mathrm{pH}$ and dissolving calcareous tests. This inference is supported by our field observations of low water pH in July 2019, since accumulated precipitation was high between March and July 2019. Increased precipitation likely enhanced surface runoff into the lagoon, resulting in the accumulation of high quantities of organic material. This dissolution mechanism could explain the progressive decline in abundance of calcareous benthic foraminifera in the lagoon, between the time span encompassed by the studies of Closs and Madeira (1967), Leipnitz et al. (2014) and, now, our study.

Two weak aspects of our study are the small number of sampling points (stations) and the small number of recovered specimens throughout the year. Future studies in the area should focus on broadening the sampling area along with increasing the sediment volume analyzed. Such an effort would potentially enable the recognition of statistically significant abundance trends and to recover richer benthic foraminiferal assemblages, allowing better constraint of the general trends depicted by our study.

Relative abundances of Deformed benthic FORAMINIFERAL TESTS

Relative abundances of specimens with deformed tests peaked above $16 \%$ in the samples collected from the Tramandaí-Armazém Lagoon in January and March 2019, when population densities usually rise in Tramandaí and Imbé (Zuanazzi and Bartels, 2016). These estimates consider together the living 
and dead specimens, and suggest a possible role for contamination of the lagoonal waters by domestic and/or industrial residues (e.g., Geslin et al., 2002; Frontalini et al., 2018).

Nevertheless, we cannot rule out a possible influence of the restricted coastal environment of the lagoon on the frequency of deformed tests, as a response to rapid variations of environmental conditions. Closs and Madeira (1967) showed that foraminiferal assemblages from inner areas of the Tramandaí-Armazém Lagoon, where water salinity is lower, tend to present variations in wall thicknesses, chamber arrangement, ornamentation and the general aspect of apertures. In fact, high frequency oscillations of physical and chemical water parameters can also be associated with increased abundances of deformed tests (e.g., Bouchet et al., 2018).

\section{CONCLUSION}

In this study, we compared benthic foraminiferal counts of living and dead specimens recovered from surface sediments of the Tramandaí-Armazém Lagoon with physical and chemical characteristics of the water, as well as meteorological data for the region. Our study revealed that benthic foraminiferal populations of the lagoon increased in size (total abundances) during the wetter months of March and July 2019, when assemblages became dominated by the species Ammotium salsum, probably due to increased fresh water and organic matter supply. Furthermore, our study suggests that human impact on the region increases the abundance of deformed tests among the modern benthic foraminifera. This would be specially the case during warmer months, when human occupation in the coastal region of Rio Grande do Sul increases, although further studies will be necessary to test this hypothesis.

\section{ACKNOWLEDGMENTS}

We thank itt Fossil (UNISINOS University) for technical support and the facilities used in this research, and to the Federal University of Rio Grande do Sul (UFRGS) and Centro de Estudos Costeiros, Limnológicos e Marinhos (Ceclimar) for collaboration during sampling campaigns. We are grateful to two anonymous reviewers and to associate editor Fabrizio Frontalini for constructive comments that greatly improved the manuscript.

\section{AUTHOR CONTRIBUTIONS}

E.P.M: Conceptualization, Data curation, analysis, Writing - original draft, Writing - review \& editing.

K.G.D.K.: Conceptualization, analysis, Resources, Writing - review \& editing.

C.T.B.: Conceptualization, Resources, Validation, Writing - review \& editing.

\section{REFERENCES}

BARBOZA, E. G, TOMAZELLI, L. J., DILLENBURG, S. R. \& ROSA, M. L. C. C. 2008. Planície Costeira do Rio Grande do Sul: Erosão em Longo Período. Revista de la Sociedad Uruguaya de Geología, 15, 94-97.

BOUCHET, V. M. P., GOBERVILLE, E. \& FRONTALINI, F. 2018. Benthic foraminifera to assess ecological quality statuses in Italian transitional water. Ecological Indicator, 84, 130-139.

CLOSS, D. 1962a. Foraminíferos e tecamebas da Lagoa dos Patos (RGS). Boletim da Escola de Geologia de Porto Alegre, 11, $1-130$.

CLOSS, D. \& MADEIRA, M. L. 1962b. Tecamebas e foraminíferos do Arroio Chuí (Santa Vitória do Palmar, RS). Iheringia, Série Zoológica, 19, 1-44.

CLOSS, D. \& MADEIRA, M. L. 1967. Foraminíferos e tecamebas aglutinantes da lagoa de Tramandaí, Rio Grande do Sul. Iheringia, Série Zoológica, 35, 7-31.

CLOSS, D. \& MADEIRA, M. L. 1971. Distribuição ecológica dos foraminíferos e tecamebas (Protozoa) nas planícies costeiras do Sul do Brasil. Arquivos do Museu Nacional, 54, 31-32.

CLOSS, D. \& MEDEIROS, V. M. F. 1967. Thecamoebina and foraminifera from the Mirim lagoon, southern Brazil. Iheringia, Série Zoológica, 35, 75-88.

COCCIONI, R., FRONTALINI, F., MARSILI, A. \& MANA, D. 2009. Benthic foraminifera and trace element distribution: a case-study from the heavily polluted lagoon on Venice (Italy). Marine Pollution Bulletin, 59(8-12), 257-267.

CROUDACE, I. W. \& ROTHWELL, R. G. 2015. Micro-XRF studies of sediment cores: applications of a non-destructive tool for the environmental Sciences. Heidelberg: Springer-Verlag.

FRONTALINI, F., BUOSI, C., PELO, S., COCCIONI, R., CHERCHI, A. \& BUCCl, C. 2009. Benthic foraminifera as bio-indicators of trace element pollution in the heavily contaminated Santa Gilla lagoon (Cagliari, Italy). Marine Pollution Bulletin, 58(6), 858-877.

FRONTALINI, F., GRECO, M., BELLA, L., LEJZEROWICZ, F., REO, E., CARUSO, A., COSENTINO, C., MACCOTTA, A., SCOPELLITI, G. NARDELLI, M. P., LOSADA, M. T., CHÂTELET, E. A., COCCIONI, R. \& PAWLOWSKI, J. 2018. Assessing the effect of mercury pollution on cultured benthic foraminifera community using morphological and eDNA metabarcoding approaches. Marine Pollution Bulletin, 129(2), 512-524.

GESLIN, E., DEBENAY, J. P., DULEBA, W. \& BONETTI, C. 2002. Morphological abnormalities of foraminiferal tests in Brazilian environments: comparison between polluted and non-polluted areas. Marine Micropaleontology, 45(2), 151-168.

HASENACK, H. \& FERRARO, L. 1989. Considerações sobre o clima da região de Tramandaí, RS. Pesquisas em Geociências, 22(22), 53-70. 
INMET (Instituto Nacional de Meteorologia). Dados Meteorológicos da Estação Automática de Tramandaí [online]. Brasília: INMET. Available at: http://www.inmet.gov.br

IBGE (Instituto Brasileiro de Geografia e Estatística). IBGE em parceria com a Marinha do Brasil lança o atlas geográfico das zonas costeiras e oceânicas [online]. Rio de Janeiro: IBGE. Available at: https://censo2010.ibge.gov.br/noticias-censo.html?busca $=1$ \&idnoticia $=2036 \& \mathrm{t}=\mathrm{ibge}$-parceria-marinha-brasil-lanca-atlas-geografico-zonas-costeiras-oceanicas\&view=noticia.html

LEIPNITZ, I. I., NOWATZKI, C. H., LEIPNITZ, B., AGUIAR, E. S., OLIVEIRA, R. F. G. \& GIOVANONI, L. 2003. Foraminíferos do Quaternário da Lagoa do Peixe, estado do Rio Grande do Sul, Brasil. Revista Brasileira de Paleontologia, 5, 39-47.

LEIPNITZ, I. I., FERREIRA, F., LEÃO, C. J., CHÂTELET, E. A. \& FRONTALINI, F. 2014. Foraminiferal and testate amoeba diversity, distribution and ecology in transitional environments of the Tramandaí Basin (Rio Grande do Sul, South Brazil). Marine Biodiversity, 44(3), 415-434.

MARTINS, M. V. A., HOHENEGGER, J., FRONTALINI, F., LAUT, L., MIRANDA, P., RODRIGUES, M. A., DULEBA, W., GERALDES, M. C. \& ROCHA, F. 2018. Heterogeneity of environments in a coastal lagoon mouth by the comparison between living and dead benthic foraminiferal assemblages (Ria de Aveiro, Portugal). Estuarine, Coastal and Shelf Science, 213, 199-216.

MORENO, J., FATELA, F., LEORRI, E. \& MORENO, F.2017. Records from marsh foraminifera and grapevine growing season temperatures revel the hydro-climatic Evolution of the Minho Region (NW Portugal) from 1856-2009. Journal of Foraminiferal Research, 47(2), 208-218.

MURRAY, J. W. 1991. Ecology and paleoecology of benthic foraminifera. London: Routledge.

MURRAY, J. W. 2006. Ecology and applications of benthic foraminifera. New York: Cambridge University Press.
RAPOSO, D., CLEMENTE, I., FIGUEIREDO, M., VILAR, A., LORINI M. L., FRONTALINI, F., MARTINS, V., BELART, P., FONTANA, L., HABIB, R. \& LAUT, L. 2018. Benthic foraminiferal and organic matter compounds as proxies of environmental quality in a tropical coastal lagoon: the Itaipu lagoon (Brazil). Marine Pollution Bulletin, 129(1), 114-125.

SCHÖNFELD, J., ALVE, E., GESLIN, E., JORISSEN, F., KORSUN, S., SPEZZAFERRI, S. \& MEMBERS OF THE FOBIMO GROUP 2012. The FOBIMO (Foraminiferal Bio-MOnitoring) initiatiave - towards a standardised protocol for soft-bottom benthic foraminiferal monitoring studies. Marine Micropaleontology, 94-95, 1-13.

SNIS (Sistema Nacional de Informações sobre Saneamento). Ministério do desenvolvimento regional. Agrupamento dinâmico de indicadores e informações municipais por ano de referência [online]. Brasília: SNS. Available at: http://app4. mdr.gov.br/serieHistorica/residuosSolidos/index

TABAJARA, L. L. \& DILLENBURG, S. R. 1997. Batimetria e sedimentos de fundo da laguna de Tramandaí - RS. Notas Técnicas CECO/IG/UFRGS, 10, 21-33.

TOMAZELLI, L. J. \& VILLWOCK, J. A. 2005. Mapeamento geológico de planícies costeiras: o exemplo da costa do Rio Grande do Sul. GRAVEL, 18(2), 99-103.

WILDNER, W., RAMGRAB, G. E., LOPES, R. D. \& IGLESIAS, C. D. F. 2008. Geologia e recursos minerais do estado do Rio Grande do Sul: escala 1:750.000. Porto Alegre: CPRM (Companhia de Pesquisa de Recursos Minerais).

WÜRDIG, N. L. 1987. Alguns dados físicos e químicos do sistema lagunar de Tramandaí, Rio Grande do Sul. Pesquisas, 20, 49-74.

ZUANAZZI, P. T. \& BARTELS, M. 2017. Estimativa para a população flutuante do litoral norte do RS [online]. Porto Alegre: FEE (Fundação de Economia e Estatística). Available at: https://www.fee.rs.gov.br/wp-content/uploads/2016/07/20 160711 relatorio-populacao-flutuante-do-litoral-norte.pdf 